\title{
IMPLEMENTASI KEBIJAKAN REMUNERASI DI RUMAH SAKIT PEMERINTAH
}

\section{IMPLEMENTATION OF THE REMUNERATION POLICY IN GOVERNMENT HOSPITAL}

\author{
Iwan Dakota ${ }^{1}$, Dumilah Ayuningtyas ${ }^{2}$, Ratih Oktarina ${ }^{2}$, Misnaniarti ${ }^{3}$ \\ ${ }^{1}$ Rumah Sakit Jantung dan Pembuluh Darah Harapan Kita \\ ${ }^{2}$ Progam Studi Pascasarjana Kajian Administrasi Rumah Sakit, Fakultas Kesehatan Masyarakat, \\ Universitas Indonesia, Depok \\ ${ }^{3}$ Fakultas Kesehatan Masyarakat, Universitas Sriwijaya, Indralaya
}

\begin{abstract}
Background: Since 2008, Hospital A began implementing remuneration. However, this system gets the refusal of some parties. Therefore, aims this research was to determine the remuneration policy implementation at the Hospital A Jakarta. Method: The study was conducted with a qualitative approach through in-depth interviews and focus group discussions, each with 10 medical personnel involved. Result: The results of this study indicate that aspects of the environment in general have a positive perception of the organization while the relationship between negative perceptions obtained. Negative perceptions are also found on the organization's resources and budget allocation accuracy especially bureaucratic commitment is relatively low. Meanwhile, the characteristic aspects and capabilities of implementing agencies received a positive perception. Secondary data showed an increase in financial performance and hospital services after the implementation of the remuneration. Conclusion: Implementation of the remuneration policy in Hospital A goes pretty well with a few flaws that need attention. Therefore, the necessary changes to the paradigm of gradual and continuous work culture of employees, improving the quality and quantity of communication between the organization and management of the employees regarding transparency, optimization remuneration policy dissemination and implementation of monitoring and evaluation on a regular basis with the involvement of all stakeholders.
\end{abstract}

Keyword : Implementation, Policy, Remuneration, Hospital

\section{ABSTRAK}

Latar Belakang: Sejak tahun 2008, Rumah Sakit A mulai menerapkan kebijakan remunerasi. Akan tetapi sistem ini mendapat penolakan dari sejumlah pihak. Oleh karena itu, tujuan studi ini adalah untuk mengetahui implementasi kebijakan remunerasi di Rumah Sakit A di Jakarta. Metode: Studi dilakukan dengan pendekatan kualitatif melalui wawancara mendalam dan diskusi kelompok terfokus, masing-masing dengan 10 tenaga medis yang terkait. Hasil: Hasil penelitian ini menunjukkan bahwa aspek kondisi lingkungan secara umum memiliki persepsi positif sedangkan hubungan antar organisasi didapatkan persepsi yang negatif. Persepsi yang negatif juga dijumpai pada sumber daya organisasi khususnya ketepatan alokasi anggaran dan komitmen birokrasi yang relatif rendah. Sementara, aspek karakteristik dan kapabilitas instansi pelaksana mendapat persepsi positif. Data sekunder menunjukkan adanya peningkatan kinerja pelayanan dan keuangan rumah sakit setelah pelaksanaan remunerasi. Kesimpulan: Impelementasi kebijakan remunerasi di Rumah Sakit A berlangsung cukup baik dengan beberapa kekurangan yang perlu mendapatkan perhatian. Oleh karena itu, diperlukan perubahan bertahap dan berkesinambungan terhadap paradigma budaya kerja karyawan, peningkatan kualitas dan kuantitas komunikasi antar organisasi maupun manajemen dengan karyawan menyangkut tranparansi, pengoptimalan sosialisasi kebijakan remunerasi serta pelaksanaan monitoring dan evaluasi secara berkala dengan melibatkan semua pemangku kepentingan.

Kata kunci: Implementasi, kebijakan, remunerasi, rumah rakit

\section{PENGANTAR}

Pengelolaan keuangan Badan Layanan Umum (BLU), diberikan fleksibilitas berupa keleluasaan untuk menerapkan praktik-praktik bisnis yang sehat termasuk remunerasi untuk meningkatkan pelayanan kepada masyarakat dalam rangka memajukan kesejahteraan umum dan mencerdaskan kehidupan bangsa. ${ }^{1}$ Oleh karena itu, BLU milik Kementerian Kesehatan sudah dapat menerapkan sistem remunerasi.

Implementasi remunerasi menjadi sebuah perubahan mendasar pada proses manajemen Sumber Daya Manusia (SDM), khususnya di Rumah Sakit A(selanjutnya disingkat RSA). Sistem remunerasi memberikan reward kepada karyawan berdasarkan tiga komponen utama penilaian, yaitu, "pay for people (berdasarkan tingkat pengetahuan dan kecakapan), pay for position (berdasarkan 
jabatan yang diemban), dan pay for performance (berdasarkan pencapaian prestasi kinerja yang dihasilkan). ${ }^{2}$

Khusus dalam hal jasa medis, remunerasi merupakan besaran nilai jumlah uang yang diterima oleh tenaga medis sebagai kompensasi atas kinerja yang telah dilakukan, berkaitan dengan risiko dan tanggung jawab profesi dari pekerjaannya. Perlu dipahami bahwa layanan rumah sakit merupakan hasil dari satu kerjasama berbagai unit/layanan bersama, dengan berbagai proporsi, kerja, risiko dan tanggung jawab.

Mutu pelayanan rumah sakit identik dengan kepuasan, pada pasien/masyarakat, profesional (utamanya tenaga medis), manajemen dan pemerintah. Makna profesional adalah adanya kerjasama lintas profesi dalam pelayanan di rumah sakit. Selain itu, kerjasama lintas fungsional (profesi) berperan penting dalam memfasilitasi rumah sakit mencapai efisiensi, dalam beban kerja maupun dalam bentuk anggaran dan pengeluaran materi. ${ }^{3,4,5}$ Oleh karena itu, dengan adanya sistem remunerasi maka semua profesi yang terlibat dalam pelayanan medis akan mendapat apresiasi secara lebih adil berdasarkan kinerja.

Konsekuensi dari hal ini, pada saat akan diterapkannya remunerasi di RSA banyak sekali pro dan kontra dari karyawan. Berdasarkan pengamatan diketahui bahwa sebagian besar karyawan non medik menyambut secara antusias remunerasi dengan ekspektasi tambahan pendapatan yang signifikan. Sebaliknya sikap kontra ditunjukkan kelompok dokter bedah dan kardiovaskular. Kekhawatiran ini mungkin karena kelompok ini mendapatkan take home pay yang paling tinggi pada sistem penggajian fee for service sehingga dengan diberlakukan remunerasi, pendapatan kelompok ini akan berkurang. Hal ini tentu konsekuensi dari sistem pembagian alokasi dana yang sama, terjadi peningkatan pendapatan pada sebagian besar karyawan non medik dan tentu berimbas dengan menurunnya pendapatan kelompok dokter tadi. Dengan diterapkannya sistem remunerasi, maka pendapatan kelompok dokter pada Satuan Medik Fungsional (SMF) tertentu akan berubah, dan tentu ini akan memiliki fluktuasi yang besar pula dibandingkan dengan profesi lainnya di RS.

Selain itu, banyak sekali pihak pro kontra bahkan menolak sistem remunerasi ini karena adanya asumsi akan mengurangi "take home pay" mereka, karena ada pendapat akan mensubsidi ke komponen SDM lainnya di RS. Kelompok SMF ini merupakan faktor vital dalam menjalankan proses bisnis di rumah sakit yang memberikan kontribusi pendapatan yang besar pada rumah sakit.

Adanya ketidakpuasan, khususnya dari kelompok SMF, tentu akan berimbas terhadap menurunnya motivasi kerja, dan ujungnya berimbas terhadap menurunnya kinerja dan kualitas pelayanan. Kualitas RS bisa jadi sangat ditentukan oleh pelayanan medis dari para dokter akan tetapi perludipahami pula bahwa pelayanan medis yang ada merupakan hasil kerjasama antar profesi lain di RS.

Oleh karena itu, tujuan penelitian ini adalah untuk mengetahui implementasi kebijakan renumerasi di Rumah Sakit A dilihat berdasarkan aspek kondisi lingkungan, hubungan antar organisasi, sumber daya organisasi untuk implementasi program, serta karakteristik dan kemampuan pelaksana. Diharapkan hasil penelitian ini dapat menjelaskan upaya mewujudkan reformasi birokrasi melalui kebijakan remunerasi sesuai dengan Peraturan Menpan No.15/2008.

\section{BAHAN DAN CARA PENELITIAN}

Penelitian ini merupakan penelitian kualitatif dengan rancangan studi kasus. Kerangka pikir menggunakan analisis implementasi kebijakan publik Cheema dan Rondinelli dan Keputusan Menteri Keuangan (KMK) RI Nomor : 165/Menkeu/ SK/IV/2008. Teori Cheema dan Rondinelli (1983), mengemukakan bahwa ada empat variabel yang dapat memengaruhi kinerja dan dampak suatu program, yaitu kondisi lingkungan, hubungan antar organisasi, sumber daya organisasi untuk implementasi program, serta karakteristik dan kemampuan agen pelaksana. ${ }^{2,6,7}$ Lokasi penelitian di salah satu rumah sakit publik di Jakarta. Waktu penelitian dilakukan pada 2013. Informan ada 20 orang terdiri dari pejabat terkait (direktur, kepala bagian, kepala sub bagian), dokter Satuan Medik Fungsional (SMF), perawat, dan karyawan non medis.

Data dikumpulkan dengan metode wawancara mendalam (in-depth interviews) dan Focus Group Discussion (FGD). Selain itu juga dikumpulkan data laporan RS yang berkaitan dengan informasi mengenai kinerja pelayanan dan keuangan rumah sakit serta kinerja SDM pada tahun 2006 sampai dengan 2013. Validitas data melalui metode triangulasi, yaitu triangulasi sumber, triangulasi metode, dan triangulasi analisis. Data kemudian diolah, ditelaah dan disajikan dalam tabel sesuai teori bahwa hasil disajikan dalam bentuk matriks, 
narasi dan tabulasi data. ${ }^{8}$ Reduksi data yang dilakukan melalui proses abstraksi data dengan membuat rangkuman inti, proses dan pernyataanpernyataan yang perlu dijaga sehingga tetap berada di dalamnya. ${ }^{9}$ Analisis data menggunakan analisis isi (content analysis). Selanjutnya dikaitkan dengan teori yang ada, peraturan-peraturan dan kebijakan sebagai landasan hukum remunerasi.

\section{HASIL PENELITIAN DAN PEMBAHASAN}

Berikut hasil penelitian berdasarkan empat variabel yang diyakini dapat mempengaruhi implementasi program-program pemerintah, meliputi kondisi lingkungan, hubungan antar organisasi, sumberdaya organisasi, karakteristik dan kapabilitas instansi pelaksana.

\section{Kondisi Lingkungan}

Informasi kondisi lingkungan yang digali meliputi aspek struktur pembuatan kebijakan, kendala sumberdaya eksternal, sosio kultural, derajat keterlibatan penerima program, ketersediaan infrastruktur fisik. Berdasarkan aspek struktur pembuatan kebijakan, diketahui belum banyak keterlibatan Kementerian Kesehatan dalam proses penyusunan kebijakan remunerasi berbasis kinerja tersebut. Mulai proses penyusunan kebijakan hingga implementasinya dilaksanakan dengan bantuan konsultan Sumber Daya Manusia (SDM). Proses penyusunan membutuhkan waktu hampir 9 bulan termasuk proses persiapan dan sosialisasi remunerasi. Upaya yang dilakukan oleh tim adalah menyamakan persepsi tentang remunerasi yaitu dengan melibatkan semua stakeholder, terkait pengertian remunerasi, tujuan dan proses pelaksanaannya termasuk di antaranya adalah pemetaan (mapping) karyawan yang meliputi job grade, job description, dan job value.

Kendala sumberdaya eksternal dapat disimpulkan tidak ada. Rumah sakit $A$ merupakan Badan Layanan Umum (BLU), memiliki penerimaan yang cukup besar untuk membiayai $90 \%$ pengeluaran operasionalnya. Anggaran dari Pemerintah yang diterima rumah sakit hanya sebesar $10 \%$ dari pengeluarannya untuk membiayai pengeluaran gaji Pegawai Negeri Sipil. Implementasi remunerasi berbasis kinerja tidak tergantung dari sumberdaya eksternal. Bahkan RSAingin meningkatkan kisaran remunerasi yang diterima pegawai sesuai dengan tinggi rendahnya tingkat penerimaan rumah sakit.

Terjadi perubahan sosial kultural dengan diberlakukan sistem remunerasi berbasis kinerja, yaitu terjadi perubahan paradigma bekerja di lingkungan RSA. Terjadi perubahan paradigma dari sistem penggajian yang lama khususnya fee for service (bagi kelompok medis) menjadi sistem remunerasi yang berbasis kinerja. Perubahan paradigma ini tidak mudah dilakukan khususnya bagi tenaga non medis yang dulunya menggunakan sistem penggajiannya berbasis pada penggajian PNS yang hanya berdasarkan pangkat dan golongan serta lama bekerja.

Rumah SakitA memiliki infrastruktur yang memadai dan peralatan medis yang selalu disesuaikan dengan perkembangan teknologi kedokteran pada saat ini. Sebagai sebuah rumah sakit pendidikan, selalu berupaya memenuhi kebutuhan pelayanan kardiologi dan pembuluh darah dengan peralatan yang paling baik, paling mudah digunakan dan memiliki risiko paling rendah kepada pasien serta paling efisien.

Tabel 1. Kinerja Pelayanandi Rumah Sakit A tahun 2005-2011

\begin{tabular}{crrr}
\hline Unit & Sebelum Remunerasi (2005 - 2007) & Setelah Remunerasi (2009 - 2011) & Perubahan (\%) \\
\hline Rawat Inap & & & \\
Jumlah TT & $267-325$ & $325-331$ & 23,97 \\
Jumlah pasien & 20.204 & 66.886 & 231,05 \\
BOR (\%) & 72,92 & 63,21 & $-13,32$ \\
Bedah (total) & 4.088 & 6.321 & 54,62 \\
Bedah Dewasa & 866 & 3.776 & 336,03 \\
Bedah Pediatrik & 676 & 2.518 & 272,49 \\
DI dan INB & 16.596 & 20.937 & 26,16 \\
Rawat Jalan (total) & 310.484 & 404.069 & 30,14 \\
Poliklinik Umum & 245.220 & 312.786 & 27,55 \\
Poliklinik & 65.264 & 91.283 & 39,87 \\
Eksekutif & & & \\
\hline
\end{tabular}

Sumber : Laporan RS A 


\section{Hubungan antar organisasi}

Hubungan antar organisasi yang diterapkan oleh RSA sejak awal penyusunan kebijakan remunerasi kurang melibatkan seluruh komponen SDM baik dalam proses penyusunan, implementasi, sosialisasi dan kordinasi. Sumber permasalahan justru muncul karena rendahnya keterlibatan kelompok karyawan dan minimnya informasi yang diberikan kepada para pegawai terutama dari kalangan tenaga non-medis dan paramedis mengenai harga jabatan dari posisi yang dipegangnya.

Kebijakan remunerasi yang berlaku di RSA dinilai sudah cukup jelas, begitu pula pada sasaran programnya. Tujuan penerapan remunerasi untuk meningkatkan kinerja baik pelayanan maupun keuangan dalam mencapai visi dan misi. Harapan dengan diberlakukan sistem remunerasi dapat meningkatkan kesejahteraan karyawan sehingga dapat meningkatkan motivasi dan kinerja individu maupun unit.

Tabel 1 menunjukkan bahwa peningkatan pelayanan meningkat secara signifikan setelah implementasi kebijakan remunerasi.Perbandingan kinerja tenaga medis sebelum maupun sesudah implementasi kebijakan sistem remunerasi dapat dilihat dari rata-rata jumlah pelayanan medis yang diberikan oleh masing-masing tenaga medis berbanding dengan target kinerja yang telah ditentukan oleh manajemen.

Selanjutnya pada aspek standarisasi prosedur, upaya monitoring dan evaluasi belum dilakukan secara optimal semenjak remunerasi diberlakukan pada tahun 2008. Upaya monitoring dan evaluasi pernah dilakukan secara internal dengan dibentuknya tim evaluasi dan revisi sistem remunerasi di RSA. Tim internal ini terdiri dari berbagai komponen karyawan di luar struktur pembuat kebijakan. Masukan dari tim ini sebaiknya diperhatikan dan dijadikan acuan untuk perbaikan implementasi remunerasi ke depan.

Advokasi ke instansi vertikal yang pernah dilakukan, yaitu ke Kementerian Keuangan, sedangkan ke Kementerian Kesehatan belum dilakukan. Sosialisasi ke asosiasi rumah sakit lainnya di Indonesia juga belum dilakukan secara intensif, termasuk dalam forum ilmiah nasional. Sosialisasi juga dapat berupa artikel ilmiah yang dapat disampaikan pada forum ilmiah kesehatan atau pada pertemuan dengan Asosiasi rumah sakit di Indonesia, sebagai wacana implementasi remunerasi dalam proses reformasi birokrasi pada aparatur pelayanan publik.

\section{Sumber Daya Organisasi}

Salah satu pertimbangan yang mendasari implementasi remunerasi di RSA adalah kinerja keuangan rumah sakit yang dinilai sehat dan paling mandiri pada saat ini di antara rumah sakit pemerintah yang ada di Indonesia. Sejak tahun 2008 RSA telah memiliki kemampuan membiayai $90 \%$ pengeluarannya dari pendapatan rumah sakit sendiri dan hanya menikmati $10 \%$ subsidi anggaran yang berasal dari APBN. Pendapatan rumah sakit setelah era remunerasi meningkat pesat jika dibandingkan sebelumnya, tetapi agak menurun pada tahun 2012. Hal ini dapat dilihat dari peningkatan pendapatan dan biaya yang dikeluarkan untuk belanja pegawai sebelum remunerasi pada Gambar 1.

Besarnya biaya yang dapat diberikan untuk setiap pegawai sesuai dengan harga jabatan, risiko pekerjaan, tanggung jawab pekerjaan dan jenis pekerjaan diatur dalam Keputusan Menteri

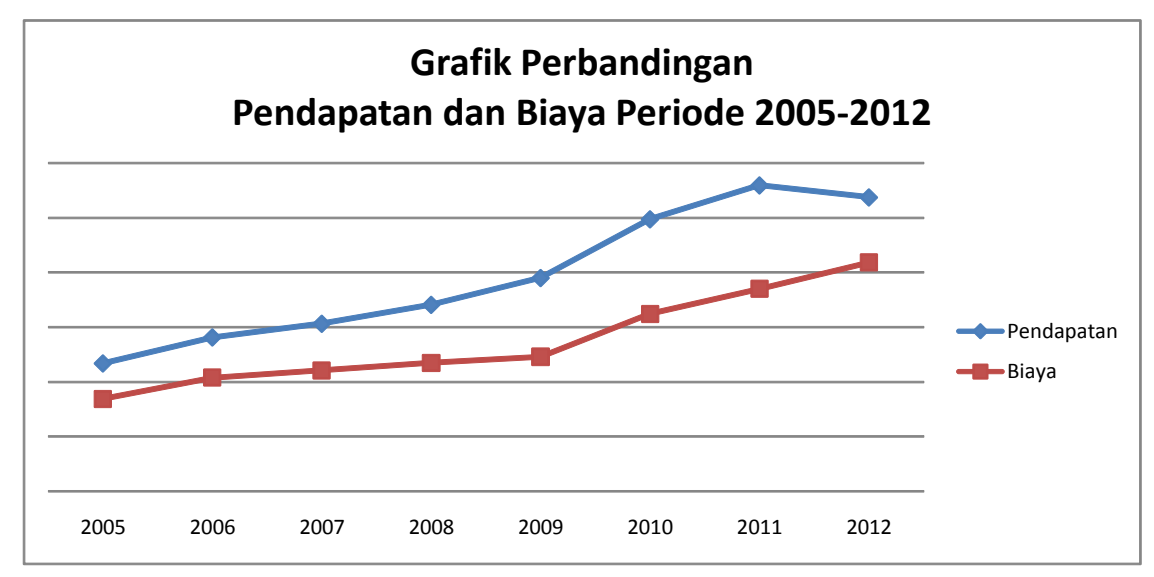

Gambar 1. Grafik Perbandingan Pendapatan dan Biaya RS Atahun 2005-2012 
Keuangan (KMK) RI nomor: 165/Menkeu/SK/ IV/2008. Besaran remunerasi tersebut telah ditetapkan maksimal sebesar $40 \%$ dari pendapatan tahun 2008. Sedangkan biaya yang dikeluarkan untuk memberikan remunerasi kepada seluruh karyawan setiap tahunnya adalah $30 \%$ dari seluruh pengeluaran rumah sakit pada tahun tersebut. Biaya yang dibutuhkan untuk belanja pegawai sebelum remunerasi berkisar antara $28 \%$ sampai $34 \%$ dari pendapatan, dan berkisar antara $27 \%$ sampai 33\% setelah diberlakukannya remunerasi. Artinya sesuai dengan KMK tersebut bahwa belanja pegawai yang digunakan untuk remunerasi memenuhi pagu di bawah $40 \%$.

Pembiayaan kegiatan yang berjalan di RSAmenurut informan sudah memadai dengan anggaran yang mencukupi. Berdasarkan informan dapat disimpulkan bahwa sebagian besar karyawan RSA puas dengan sistem remunerasi saat ini dan setuju bahwa sistem remunerasi merupakan sistem insentif yang berkeadilan. Namun, sebagian berpendapat bahwa sistem remunerasi belum efektif sebagai alat ukur penilaian kinerja. Hal ini perlu disikapi oleh sikap manajemen untuk melakukan elaborasi lebih lanjut terkait penyebab masalah pada pelaksanaan sistem remunerasi tersebut.

Alokasi anggaran untuk belanja pegawai tahun 2008 sampai tahun 2012 berkisar antara $27 \%$ sampai $33 \%$ dari pendapatan rumah sakit. Sebagian besar informan setuju dilakukan revisi remunerasi karena semenjak diberlakukan tahun 2008 alokasi anggaran untuk remunerasi belum ditingkatkan secara optimal sesuai dengan proporsi pendapatan. Hal ini penting karena menyebabkan remunerasi relatif menjadi tidak kompetitif baik untuk tenaga medis, tenaga kesehatan, maupun karyawan lainnya. Hal ini karena tidak mempertimbangkan harga pasar tenaga medis maupun tenaga kesehatan selain itu tidak terdapat peningkatan besaran pendapatan yang signifikan.

Adapun pada tahun 2011 dengan pendapatan lebih dari Rp.600 M, persentase belanja pegawai hanya berkisar 29\%. Seharusnya masih dapat ditingkatkan sepanjang tidak melebihi pagu 40\%. Hal ini penting demi menjaga nilai kompetitif bagi tenaga medis, tenaga kesehatan, maupun karyawan lainnya.

Pemerintah pusat memberikan dukungan secara positif terhadap kebijakan remunerasi di RSA, sebagai instansi BLU pertama yang menerapkan remunerasi di Kemenkes. Selain itu, payung hukum penerapan remunerasi, yaitu Peraturan Pemerintah nomor 23/2005 mengenai pengelolaan BLU yang memberikan keleluasaan untuk menerapkan remunerasi.

Secara umum dapat disimpulkan bahwa komitmen birokrasi khususnya dari Bagian SDM sudah cukup baik. Seluruh SDM yang terlibat telah memberikan komitmen yang cukup baik terhadap implementasi kebijakan remunerasi di RSA. Namun, perlu dipertimbangkan berbagai hal yang berkaitan dengan ketidakpuasan karyawan seperti kurang transparannya penentuan harga jabatan, perhitungan kinerja dan kurangnya kemampuan komunikasi pimpinan rumah sakit kepada karyawannya.

\section{Karakteristik dan Kapabilitas Instansi Pelaksana}

Karakteristik dan kapabilitas instansi pelaksana di RSA, sebagai rumah sakit vertikal di bawah Kementerian Kesehatan dengan jenis pelayanan spesialistik kardiovaskular.Saat ini RSA menjadi pusat rujukan nasional untuk penyakit-penyakit yang berkaitan dengan masalah kesehatan Jantung dan Pembuluh Darah. Sebagai instansi BLU, RS ini memiliki kemandirian finansial yang cukup tinggi dengan penerimaan tahunan paling tinggi. Beberapa informan memegang peranan yang cukup penting di Kementerian Kesehatan dan Kementerian Keuangan dalam penerapan remunerasi di RSA.

Secara umum, bagian SDM Rumah Sakit A memiliki kemampuan teknis dan manajerial yang cukup baik dalam melaksanakan sistem remunerasi. Hal ini dapat diihat dari pelaksanaan sistem remunerasi dengan baik, tidak ada permasalahan yang terkait dengan ketepatan waktu dan keakuratan perhitungan remunerasi. Sistem dan prosedur yang ada telah dilaksanakan secara konsisten. Diketahui bahwa pada awal mendesain dan mengimplementasikan sistem remunerasi ini, Bagian SDM dibantu oleh tenaga konsultan.

Hubungan pihak manajemen dengan karyawan sebagai penerima kebijakan remunerasi masih perlu mendapatkan perhatian. Informasi ini berdasarkanpersepsi informan yang berpendapat bahwa adanya kebimbangan dan penolakan dari berbagai pihak ketika akan dilaksanakan kebijakan remunerasi, khususnya staf medis, walaupun akhirnya dapat diterima. Hal ini kemungkinan karenasosialisasi yang kurang memadai dari pihak manajemen. Berdasarkan informasi informan diketahui hampir semua memberikan persepsi negatif perihal komunikasi internal ini, 
khususnyabagian SDM dan karyawan. Hal ini karena minimnya sosialisasi dan komunikasi antara pengelola kebijakan remunerasi dengan pegawai.

Pegawai tidak memahami mekanisme dalam memberikan penilaian atas kinerja, serta tidak mengerti secara detil posisi dan statusnya dalam tingkatan harga jabatan. Minimnya informasi yang diterima oleh pegawai ini menyebabkan ketidakpuasan, perasaan curiga dan kecemburuan sosial di kalangan pegawai terutama pegawai non medis dan paramedis. Upaya sosialisasi dapat menggunakan surat edaran atau melalui media berupa informasi di websiteRSA maupun melalui majalah internal rumah sakit. Bisa juga dengan memanfaatkan acarasosial yangtidak formal seperti gathering karyawan.

Informan menilai positif terhadap kualitas kepemimpinan yang berlangsung, namun ada juga yang menilai kurang puas terhadap kepemimpinan yang ada. Adanya persepsi negatif ini perlu disikapi untuk perbaikan ke depan. Kualitas pimpinan tidak hanya ditentukan oleh kapabilitas yang dimilikinya, juga bisa ditentukan oleh efektivitas komunikasi dengan jajaran di bawahnya maupun dengan karyawan. Kemampuan mengontrol dan mengkoordinasikan keputusan pada tingkat direksi, sudah cukup baik. Begitu juga koordinasi keputusan antar unit organisasi dalam mendukung implementasikan kebijakan dinilai sudah cukup baik. Namun demikian transparansi dalam pengambilan keputusan masih cukup rendah.

Dapat disimpulkan bahwa upaya yang dilakukan dalam proses persiapan implementasi remunerasi di RSA sudah sesuai dengan langkahlangkah normatif impelementasi kebijakan secara umum. Langkah-langkah yang dilakukan pada prinsipnya telah memenuhi dasar-dasar proses manajemen kompensasi (reward management process).

Kondisi struktural yang mencakup kepemimpinan di rumah sakit dapat berpengaruh terhadap implementasi suatu kebijakan yang berdampak pada kinerja rumah sakit tersebut. Menurut Griffith dkk, faktor yang ikut berpengaruh pada kinerja rumah sakit adalah faktor kepemimpinan dan manajemen serta faktor tenaga kerja dan beban kerja. ${ }^{10}$

Perubahan sosial dalam sistem remunerasi lebih menitikberatkan kepada pencapaian target kinerja individu dan unit yang sudah ditetapkan sebelumnya, tidak lagi hanya berdasarkan lama bekerja dan pangkat golongan. Budaya kerja yang berkembang di RSA menerapkan disiplin yang tinggi kepada karyawan. Setiap karyawan wajib datang tepat pada waktunya dan pulang pada waktunya. Sistem remunerasi mendorong ketaatan karyawan terhadap kedisiplinan kerja karena dengan sistem remunerasi berbasis kinerja, karyawan yang tidak disiplin akan mendapat penilaian kinerja yang rendah dan akan berdampak pada remunerasi yang akan diterima.

Keterlibatan karyawan dalam kebijakan remunerasi di RSA ini dinilai kurang. Penerapan suatu kebijakan sangat diperlukan peran serta dari pelaksana kebijakan tersebut. Begitu juga pada transparansi, menjadi hal yang sangat krusial dalam penerapan remunerasi. Transparansi adalah keterbukaan di mana karyawan dapat mengetahui grade atau peringkat job decription atau tupoksinya, job value atau nilai pekerjaannya serta job price (harga pekerjaannya).

Upaya monitoring dan evaluasi di RSA belum dilakukan secara optimal semenjak remunerasi tahun 2008. Menurut Suyanto ${ }^{11}$, bahwa supervisi diartikan sebagai pengamatan atau pengawasan secara langsung terhadap pelaksanaan pekerjaan yang sifatnya rutin. Selaras dengan penelitian llyas, ${ }^{12}$ bahwa faktor yang berkaitanlangsung dengan kinerja seorang dokter yaitu penghasilan, manfaat supervisi, pengembangan karier, dan pelatihan. Hal ini pula yang sedikit banyak mempengaruhi penerimaan SDM (seperti dokter SMF) terhadap implementasi kebijakan remunerasi. Dengan kata lain, faktor-faktor tersebut bisa meningkatkan kinerja personal dan organisasi. ${ }^{13}$

Secara konsep, monitoring dan evaluasi diperlukan pada penerapan manajemen kompensasi. Evaluasi diperlukan untuk menilai hambatan dan kekurangan dalam penerapan remunerasi untuk selanjutnya dapat dijadikan acuan untuk pengembangan proses kompensasi yang lebih baik. Proses remunerasi adalah suatu proses evaluasi yang terus berkembang sesuai dengan kondisi kinerja suatu perusahaan. Artinya, monitoring dan evaluasi sangat diperlukan dalam perkembangan mekanisme sistem remunerasi yang disesuaikan dengan waktu yang berjalan. ${ }^{14}$

Dukungan dari jejaring terhadap implementasi program atau kebijakan di RSA jelas penting keberadaannya. Penerapan remunerasi diRSA dapat menjadi percontohan bagi rumah sakit lain. Kedudukan RS inisebagaipusat rujukan nasional memiliki kekuatan untuk membentuk jaringan karena ada fungsi untuk membina Pusat Jantung Regional di seluruh Indonesia. Kekuatan ini akan berpengaruh terhadap rumah sakit vertikal maupun 
RSUD. Jejaring ini meliputi ARVI (Asosiasi Rumah Sakit Vertikal Indonesia), Asosiasi Rumah Sakit Pendidikan Indonesia (ARSPI). Ini seharusnya menjadi modal bagi RSA dalam melakukan advokasi dan sosialisasi penerapan remunerasi.

Pembiayaan kegiatan yang berjalan di RS A sudah memadai dengan anggaran yang mencukupi. Hal ini dikarenakan tingkat pendapatan rumah sakit yang cukup tinggi. Selaras dengan Siregar bahwa $57,1 \%$ karyawan puas dengan sistem remunerasi dibandingkan dengan sistem penggajian yang lama. Tetapi 58,6\% karyawan tidak setuju bahwa sistem remunerasi efektif untuk penilaian kinerja. $59,8 \%$ setuju bahwa sistem remunerasi merupakan sistem insentif karyawan yang berkeadilan..$^{15}$

Diketahui bahwa belanja pegawai untuk remunerasi hanya berkisar dari $27 \%$ sampai $33 \%$ dan tidak pernah melewati pagu $40 \%$ yang ditetapkan oleh KMK 165/2008. Seharusnya peningkatan pendapatan harus diiringi dengan peningkatan porsi belanja pegawai untuk remunerasi sehingga karyawan dapat menikmati hasil yang didapatkan dari kerja keras.

Kelemahan dari KMK 165/2008 adalah menetapkan besaran absolut untuk belanja pegawai (remunerasi), tetapi bukan proporsi yang sesuai dengan pendapatan yang dihasilkan. Dukungan pemerintah berupa Grand design reformasi birokrasi yang ditetapkan berdasarkan Peraturan Menteri Negara Pendayagunaan Aparatur Negara dan Reformasi Birokrasi Nomor 20/2010 tentang Road Map Reformasi Birokrasi 2010-2014. ${ }^{16,17,18,19}$

Permasalahan birokrasi dan SDM dapat diatasi dengan meningkatkan komunikasi yang intens antara pihak manajemen dengan karyawan. Sosialisasi perlu dilakukan agar ada transparansi dalam penerapan sistem remunerasi. Perlu diperbanyak wadah komunikasi antara pihak manajemen dengan karyawan, secara formal melalui workshop maupun secara non formal melalui acara sosial (gathering karyawan) yang disisipkan pesan-pesan mengenai remunerasi.

Komunikasi internal dalam persiapan dan implementasi juga berpengaruh terhadap keberhasilan kebijakan remunerasi. Menurut Armstrong dan Murlis, ${ }^{14}$ optimalisasi media komunikasi selain cara-cara formal antara lain seperti kampanye poster, surat pembaca, email secara personal, brosur, briefing tim dalam acara-acara sosial nonformal. Hal ini perlu menjadi perhatian karena implementasi kebijakan perubahan status kelembagaan rumah sakit berpengaruh secara signifikan terhadap kualitas pelayanan, khususnya faktor komunikasi yang mempunyai pengaruh paling besar. ${ }^{20}$

Diharapkan kebijakan remunerasi ini terus dilanjutkan, karena sistem anggaran yang berorientasi kepada kinerja merupakan merupakan sistem penganggaran yang mempunyai banyak keunggulan positif dan kemaslahatan publik dibandingkan dengan sistem anggaran tradisional. Dana rumah sakit yang terbatas akan dapat memenuhi keperluan rumah sakit yang sangat banyak, serta mengandung unsur pengendalian biaya. Sehingga seluruh alokasi dana, mempunyai tujuan, sasaran, dan target kinerja secara jelas. ${ }^{21}$

Ditemukan pengaruh yang nyata dari sistem pembayaran pada perilaku dokter. Dokter dengan layanan fee for servicessecara signifikan memberikan layanan medis secara berlebihan daripada dokter dengan sistem kapitasi. ${ }^{22}$ Hasil penelitian di Jerman juga membuktikan bahwa reformasi sistem remunerasi mempengaruhi supplyside pelayanan rawat jalan. Sehingga kebijakan dari sisi supplai (supply-side) mungkin menjadi instrumen yang lebih baik untuk pengendalian biaya. Sistem remunerasi ini juga untuk mengurangi inefisiensi akibat asimetri informasi antara dokter dan pasien. ${ }^{23}$

\section{KESIMPULAN DAN SARAN}

Impelementasi kebijakan remunerasi di Rumah Sakit $A$ telah berlangsung cukup baik dan sesuai dengan KMK 165 tahun 2008 yang dibuktikan dengan meningkatnya kinerja pelayanan dan keuangan sebelum dan setelah pelaksanan remunerasi. Namun, ada beberapa kekurangan yang perlu mendapatkan perhatian, yaitu kondisi lingkungan berupa sosio kultural dimana masih terdapat etos kerja karyawan yang rendah, manajemen yang kurang produktif, birokrasi yang belum efisien, serta adanya tenaga medis yang nyaman dengan sistem lama (fee for service). Selain itu, monitoring dan evaluasi yang belum dilakukan secara optimal sejak diberlakukan tahun 2008 , serta kurangnya komunikasi dan koordinasi antar organisasi khususnya dari pengelola program SDM.

Diharapkan agarpimpinan dan manajemen Rumah Sakit dapat memperkuat dukungan manajemen dalam membangun budaya kerja karyawan, efisiensi birokrasi dan optimalisasiproduktivitas manajemen secara bertahap dan berkelanjutan. Menetapkan kebijakan formal untuk mengintensifkan upaya monitoring 
dan evaluasi secara berkaladalam penerapan remunerasi. Dapatmengoptimalisasikan upaya komunikasi internal dengan cara meningkatkan frekuensi komunikasi tentang remunerasi baik secara formal seperti surat edaran informasi remunerasi secara berkala, workshop dan forum diskusi SDM, maupun secara informal dengan memanfaatkan semua modalitas komunikasi seperti website, majalah internal dan acara social gathering karyawan.

\section{REFERENSI}

1. Peraturan Menteri Dalam Negeri Nomor 61 Tahun 2007 tentang pedoman teknis pengelolaan keuangan Badan Layanan Umum Daerah. Jakarta: Kementerian Dalam Negeri.

2. Dawud Y. Peran proses manajemen dalam pengembangan mutu pelayanan rumah sakit. Jurnal Manajemen dan Administrasi Rumah Sakit Indonesia. 1999; 1 (I): 36-46.

3. Kalam DZ.Effect of similiarity-dissimiliarity, team cohesion, and hospital cross functional teamworks effectiveness on organizational performance. Florida: Lynn University; 2008.

4. Firdausi NJ,Wulansari RD. Upaya peningkatan kinerja rumah sakit melalui optimalisasi high performance work practices tim lintas fungsi. Jurnal Administrasi Kesehatan Indonesia. 2013; 1 (1): 75-82.

5. Nawawi I. Public policy; analisis, strategi advokasi, teori, dan praktek. Surabaya: PMN; 2009.

6. Subarsono AG. Analisis kebijakan publik: konsep, teori dan aplikasi. Yogyakarta: Pustaka Pelajar; 2012.

7. Keputusan Menteri Keuangan Nomor 165/ KMK.05/2008 tentang penetapan remunerasi bagi pejabat pengelola, dewan pengawas, dan pegawai BLU RSJPDHK. Jakarta: Kementerian Keuangan.

8. Bungin B. Content analysis dan focus group discusion dalam penelitian sosial. In B. (Ed.), Metodologi Penelitian Kualitatif. Jakarta: Rajawali Pers; 2010.

9. Moleong L. Metodologi penelitian kualitatif. PT. Remaja Rosdakarya.Bandung; 2006.

10. Griffiths P, Renz A, Rafferty AM, The impact of organization and management factors on infection control in hospitals : a scoping review, London: King's College London, University of London. 2008.
11. Suyanto. Mengenal Kepemimpinan dan manajemen keperawatan di rumah sakit. cetakan ketiga, Jogjakarta : Mitra Cendikia ; 2009

12. Ilyas Y. Kinerja, Teori, Penilaian, dan penelitian. Depok: Pusat Kajian Ekonomi Kesehatan FKM UI; 2002.

13. Widyatmini, HakimL. Hubungan kepemimpinan, kompensasi dan kompetensi terhadap kinerjapegawai Dinas Kesehatan Kota Depok. Jurnal Ekonomi Bisnis.2008; 2 (13): 163-170

14. Armstrong M, Murlis H. Reward management, a handbook of remuneration strategy and practice. London: Kogan Page; 2001.

15. Siregar NNE.Persepsi kepuasan karyawan terhadap efektivitas sistem remunerasi di RS Jantung dan Pembuluh Darah Harapan Kita tahun 2008-2010. [Tesis]. Depok: Fakultas Kesehatan Masyarakat Universitas Indonesia; 2011.

16. Peraturan Pemerintah Nomor 81 Tahun 2010 tentang grand design reformasi birokrasi $2010-$ 2025.

17. Peraturan Menteri Penerapan Aparatur Negara Reformasi Birokrasi Nomor 20 Tahun 2010 tentang road map reformasi birokrasi 20102014.

18. Peraturan Menteri Negara Pendayagunaan Aparatur Negara dan Reformasi Birokrasi Nomor 9 Tahun 2011, tentang pedoman penyusunan road mapreformasi birokrasi kementerian/lembaga dan pemerintah daerah

19. Peraturan Menteri Pendayagunaan Aparatur Negara Nomor 15 Tahun 2008 pedoman umum reformasi birokrasi.

20. Kusnadi $D$. The changing of institutional status and quality of hospital patient care in hospital. Jurnal Kesehatan Masyarakat Nasional. 2012; 7 (2): 63-67.

21. Sulistiadi, W. Sistem anggaran rumah sakit yang berorientasi kinerja untuk meningkatkan kualitas keuangan publik. Jurnal Kesehatan Masyarakat Nasional. 2008; 2 (5): 234-240.

22. Schmidt HH, Selten R, Wiesen D. How payment systems affect physicians' provision behaviour; An experimental investigation. Journal of Health Economics. 2011; 30 (4):637- 646.

23. Schmitz H.Practice budgets and the patient mix of physicians; The effect of aremuneration system reform on health care utilisation. Journal of Health Economics. 2013; 32 (6):1240-1249 